\title{
Site of ulcer lesions in diabetic foot of the elderly
}

\author{
A Bruttocao ${ }^{1 *}$, C Terranova ${ }^{2}$, B Martella ${ }^{1}$, S Spirch ${ }^{1}$, R Nistri ${ }^{1}$, M Gruppo ${ }^{1}$, F Mazzalai ${ }^{1}$, R Lorenzetti ${ }^{1}$, C Militello ${ }^{1}$ \\ From de Senectute: Age and Health Forum \\ Catanzaro, Italy. 5-7 December 2009
}

\section{Clinical background}

In diabetic patients, especially if elderly, skin ulcers of the foot are among the most debilitating complications. The main risk factors for the ulcer development are diabetic neuropathy (sensory, autonomic), lower limb ischemia (diabetic arteriopathy), limited mobility and altered plantar pressure.

The aim of the study was to evaluate the different sites of the diabetic ulcers with regard to their origin.

\section{Materials and methods}

From 01.01.2004 to 31.12.2008, 402 diabetic patients were evaluated: 296 were over 65 years old (median age: $78.5 \pm 6.2$ years), with comprehensive 639 ulcers in lower limbs; The inclusion of subjects in the study was considered ethically through a correct assessment by medical examiner.

These lesions were divided into 3 groups by their origin: naturopathic, ischemic and neuroischemic.

\section{Results}

No differences were found in the lesion distribution in patients younger than 65 (not a statistically comparable number), while in the others (patients over 65 years old) there was a clear difference of site: in naturopathic patients the ulcers incidence were more in the plantar surface of the foot $(52.1 \%)$, especially in metatarsal heads area (49.6\%). The ischemic group had the most frequent ulcer sites in the extremitiesof toes (68.5\%), while the neuroischemic lesions were located on both plantar surfaces (59.8\%).

\section{Conclusions}

The different distribution of ulcers in the elderly groups was statistically significant and it seems to be correlated with their etiology $(\mathrm{p}<0.0001)$.
Author details

${ }^{1}$ Clinic of Geriatric Surgery, Hospital University of Padua, Italy . ${ }^{2}$ Unit of Forensic Toxicology and Antidoping, Hospital University of Padua, Italy .

Published: 19 May 2010

doi:10.1186/1471-2318-10-S1-A47

Cite this article as: Bruttocao et al.: Site of ulcer lesions in diabetic foot of the elderly. BMC Geriatrics 2010 10(Suppl 1):A47.
Submit your next manuscript to BioMed Central and take full advantage of:

- Convenient online submission

- Thorough peer review

- No space constraints or color figure charges

- Immediate publication on acceptance

- Inclusion in PubMed, CAS, Scopus and Google Scholar

- Research which is freely available for redistribution
C Biomed Central 